\title{
GYVENAMŲJŲ IR DARBO PATALPŲ APLINKOS ORO SĄLYGŲ VERTINIMO KOKYBIŠKUMO IR TIKSLUMO TYRIMAS NAUDOJANT PLAČIAI METROLOGIJOJE TAIKOMUS TERMOANEMOMETRUS
}

\author{
Agnè Bertašienė \\ doktoranté, jaunesnioji mokslo darbuotoja, \\ Lietuvos energetikos institutas, \\ el.p.agne@mail.lei.lt
}

\begin{abstract}
Anotacija. Oras, esantis gyvenamosiose ir biuro patalpose, naudojamas veikiant ivvairiems faktoriams, priklausomai nuo patalpu paskirties. Negrynas oras tampa kenksmingas ar net pavojingas gyventojams, pastatu konstrukcijai ir įrangai. Todèl reikia užtikrinti nuolatini oro cirkuliavimą. Šio darbo tikslas - parodyti, kad oro srauto savybių tyrimams reikia ne tik tinkamų matavimo priemoniu̧, norint ịvertinti srauto tėkmès parametrus, bet ir ypatingą dèmesį skirti detaliam mikroaplinkos (oro judèjimo ir jo pasiskirstymo, pulsacijų, temperatūros ir drègmės kitimo) tyrimui, prietaisų tiksluminėms charakteristikoms ir jų naudojimo sąlygų nustatytų reikalavimų atitikčiai.
\end{abstract}

Reikšminiai žodžiai: mikroklimatas, oro srautas, greitis, temperatūra, drėgmè.

\section{Ivadas}

Pastaruoju metu vis aktualesnè problema tampa mikroklimato patalpu, kuriose žmogus praleidžia didelę dali dienos, kokybè. Sveiko būsto ir darbui palankios aplinkos klausimai gvildenami tiek specialistu, tiek masinèje spaudoje. Patalpų oro kokybė griežtai vertinama kontroliuojančiu institucijų, siekiant užtikrinti energetinių šalies išteklių saikingą vartojimą ir žmonių sveikatingumo lygi.

Oras, esantis gyvenamosiose ir biuro patalpose, naudojamas veikiant ivvairiems faktoriams, priklausomai nuo patalpų paskirties. Negrynas oras tampa kenksmingas ar net pavojingas gyventojams, pastatu konstrukcijai ir irangai. Todèl reikia užtikrinti nuolatinị oro cirkuliavimą. Pagrindinè šildymo, ventiliacijos ir oro kondicionavimo (ŠVK) sistemų užduotis ir yra padaryti patogia, sveiką aplinką žmonems, eikvojant mažiausiai sąnaudų ir minimaliai teršiant gamtą. Iprastas patalpos védinimas gali sukelti per didelį ir per staigų oro judejjimą kenksmingą sveikatai skersvèji, prarandant dideli šilumos kieki. ŠVK sistemose optimaliai kontroliuojamas oro drègnumo lygmuo, temperatūra ir oro judejjimas (Nielsen et al. 1978), t. y. pastatu vidaus aplinkos parametrai. Nekontroliuojami oro srautai, netinkamas ju paskirstymas didina energijos sąnaudas, gali sukelti neigiamų padarinių darbuotoju sveikatai ir aplinkoje esančiai irangai (Straube 2001).

Šio darbo tikslas - parodyti, kad oro srauto savybių tyrimams reikia ne tik tinkamu matavimo priemoniu norint ivvertinti srauto tékmès parametrus, bet ir ypatingą dèmesi skirti detaliam mikroaplinkos (oro judejjimo ir pasiskirstymo, pulsaciju, temperatūros ir drègmės kitimo) tyrimui, prietaisu tiksluminèms charakteristikoms ir ju naudojimo sąlygų nustatytų reikalavimų atitikčiai.

\section{Oro judėjimas ir šiluminės aplinkos patalpụ parametrai}

Patalpose mikroklimatą lemia trys pagrindiniai oro veiksniai - oro temperatūra $(T)$, drègmė $(R h)$ ir judejjimas $(v)$. Kompleksinis jų veikimas suformuoja žmogaus šiluminę savijautą patalpose. Oro judejimą patalpose gali sukelti tiek natūralios konvekcinès srovès, tiek mechaninė ventiliacija.

Oro judejjimo greitis patalpose turètų būti iki $0,3 \mathrm{~m} / \mathrm{s}$, tai sąlygoja mus supančio oro kaitą ir galimybę kvèpuoti švaresniu oru. Žmogaus organizmas pradeda jausti oro judejjimą, kurio greitis yra $0,15 \mathrm{~m} / \mathrm{s}$.

Kokios yra optimaliausios sąlygos žmogui, individualiai sunku nusakyti, tačiau tą bendrai nusako LR SAM patvirtinta higienos norma HN 42:2004 „Gyvenamujų ir viešojo naudojimo pastatu mikroklimatas“ (HN 42:2004. 2004-07-06), kurioje išskiriamos pakankamos ir komfortinės šiluminès aplinkos parametru normuojamos vertès. Pakankamas oro judèjimo greitis yra $0,05-0,1 \mathrm{~m} / \mathrm{s}$ ir $0,15-0,5 \mathrm{~m} / \mathrm{s}$ atitinkamai šaltuoju ir šiltuoju metu laikotarpiu, komfortui $-0,15$ ir $0,25 \mathrm{~m} / \mathrm{s}$, santykinio aplinkos drègnumo diapazonai - 30-75 \% ir 40-60\%, pakankama temperatūra $18-26{ }^{\circ} \mathrm{C}$ ir $22-28{ }^{\circ} \mathrm{C}$, tuo tarpu komfortui $20-24^{\circ} \mathrm{C}$ ir $23-25^{\circ} \mathrm{C}$. Senos statybos gyvenamuosiuose 
namuose, viešojo naudojimo pastatuose tokias sąlygas užtikrinti sudètinga dèl nekokybiškos statybos, netinkamos patalpų termoizoliacijos, nepakankamo šildymo, prastos ventiliacijos ar netinkamos priežiūros.

\section{Aplinkos sąlygų parametrams matuoti naudojamos priemonès ir eksperimentiniai tyrimai}

Praktikoje tiriant aplinkos srautus naudojamos ivairiais principais veikiančios matavimo priemonès (MP). Populiariausi prietaisai mažiems srautams yra termoanemometrai (TA), dažniausiai pagrissti pastovios temperatūros principu, turintys triju tipu jutiklius - tai vielelè, plèvelè arba sfera (Jorgensen 2005; Measuring instruments for velocity 2008). TA yra jautrūs prietaisai, kurių matavimo diapazonas yra 0-15(20) m/s, tačiau greičio vertė gaunama iš šilumos pernašos nuo prietaiso jutiklio i supančią aplinka, todèl reikia tikslaus pasikartojančio kalibravimo ir taikymo aplinkos kalibravimo sąlygu atitikties.

Be TA, praktikoje naudojami skirtuminio slėgio matavimais pagristi statiniai, Pito vamzdeliai, mechaniniai anemometrai, tačiau pastarieji naudojami didesniems srautu greičiams matuoti. Laboratorijos sąlygomis minètiems MP kalibruoti naudojami banginiais matavimo principais pagristi ultragarsiniai (UA) ir lazeriniai Doplerio anemometrai (LDA). Šios MP pasižymi dideliu matavimo tikslumu, yra neinvazinès ir mažiau reaguoja $i$ aplinkos poveikius. Būtent dèl šiu MP galima ìvertinti praktikoje naudojamų darbiniu MP tikslumines charakteristikas ir jais fiksuojamų greičio verčių realių verčių atitikti.

Šiuo metu Lietuvoje $0,2-60 \mathrm{~m} / \mathrm{s}$ oro greičio vertèms patikimai atkurti naudojamas kompleksas priemoniu, susidedančių iš aerodinaminio įrenginio, vidutines greičio vertes atkuriančiu UA ir vietini greitị tam tikrame srauto taške atkuriančio LDA. Verčių perdavimo neapibrèžtis šiame intervale sudaro $\pm 2,5-0,3 \%$. Preliminariai įvertintos neapibrěžtys esant oro greičio vertėms $0,05-0,2 \mathrm{~m} / \mathrm{s}$ sudaro $\pm 15-2,5 \%$ (Pedišius et al. 2009). TA tikslumo vertinimo tyrimai, atlikti šio irenginio matavimo kanalo pradiniame ruože, kuriame nustatytas greičio pasiskirstymas, patvirtinta gera skirtingomis MP atkuriamų verčiu koreliacija esant $0,01-0,5 \mathrm{~m} / \mathrm{s}$ oro greičiui (Pedišius et al. 2008).

Didesnių nei $3 \mathrm{~m} / \mathrm{s}$ greičiu, atitinkančių turbulentinio tekèjimo režima, matavimas yra ne toks sudètingas. Mažejjant greičiui ir artėjant laminarinio tėkmès režimo link susiduriama su pereinamojo tekèjimo reiškiniais. Oro greičio verčių atkūrimas, esant mažesniems nei $R e_{D} \leq 10^{4}$ (atitinka 0,4 m/s atkuriamą greiti), tampa komplikuotas dèl pereinamojoje iš laminarinès i turbulentinę tėkmę srityje padidejusio $\mathrm{Tu}$ ir srauto nestabilumu. Kalbant apie komfortinių sąlygu parametrus, oro judejjimo greitis atitinka būtent minètają pereinamają sritį. Todèl atkuriant mažus $0,05-0,2 \mathrm{~m} / \mathrm{s}$ oro greičius svarbu atsižvelgti i esamus srauto nestabilumus, ivertinti kitų paveikiujų veiksnių itaką perduodant atkurtas vertes darbiniams matuokliams ir atliekant matavimus realiomis sąlygomis.

TA vienas svarbiausių veiksnių, turinčių įtakos verčių svyravimams, yra tėkmès režimas ir Tu lygmuo, taip pat kalibruojamojo matuoklio orientacija i tėkmės kryptị. Reikia paminèti, kad svarbus yra ir natūraliosios konvekcijos pasireiškimas esant mažiems oro srautams ir jutiklio formai. Atliekant matavimus realiomis sąlygomis svarbiausia îvertinti šių sąlygų ir kalibravimo sąlygų atitiktị ir jų galimą itaką matavimo rezultatui. Geometrinių sąlygu skirtumai veikia MP jutiklio aptekèjimo intensyvumą, tèkmès parametrai - Tu lygmens, nestabilumu ir kintančios krypties kitima, oro parametrų $\Delta p, T$ ir $R h$ bei sudèties kitimas tiesiogiai veikia matuojamos vertès dydžio fluktuacijas.

Atlikus eksperimentus akivaizdu, kad Tu laipsnis, esant turbulentinei tėkmei, yra pastovus tiek uždarame kanale, tiek atvirame kanale ir mažai nukrypsta nuo 1$2 \%$ (1 pav.), tačiau artejjant pereinamosios tèkmès link jis didejja ir pasiskirsto netolygiai 2-8 \% (2 pav.). Kadangi srautas šiuo režimu tampa nestabilus, didejja rezultatų sklaida. Tai turi neišvengiamai veikti greičio verčių atkūrimo neapibrèžti ir taip pat verčiu perdavimą MP, priklausomai nuo TA jutiklio tipo.

Greičio vertès priklausomybè nuo $T$ ir $T u$ parodyta 3 pav., kuriame maksimali matuoklio vertė keičiasi pagal abu parametrus. Greičio vertė kinta ir nuo to, ar MP dedama i srautą tinkamu kampu ir ar teisingai parenkama jo kryptis srauto atžvilgiu (4 pav.). Kaip rodo rezultatai, sferinis TA jutiklis yra mažiau jautrus aplinkos parametru pokyčiams, vielelès formos jutiklio TA smarkiai reaguoja i pereinamosios srities nestabilumus, TA vertès padideja, lyginant su etaloniniu anemometru.

Jautrus išorès poveikiui yra tas TA, kurio jutiklis vielelè ar sfera yra be apsaugos. TA su apsauga išorinis $\mathrm{Tu}$ laipsnis neveikia.

Sferinio TA priklausomybè nuo pasukimo kampo taip pat minimaliai veikia matuojamą oro greičio vertę (5 pav.). Plèvelès jutiklio TA vertès yra didesnès nei LDA ir iki pereinamosios srities išsilaiko gana stabilios. 


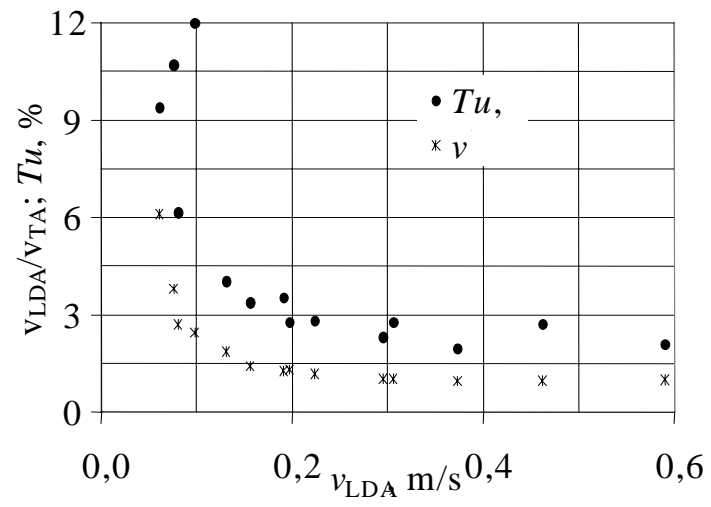

1 pav. Tu intensyvumo ir $v$, matuotų LDA ir TA, santykis priklausomai nuo $v$ (max) vertès

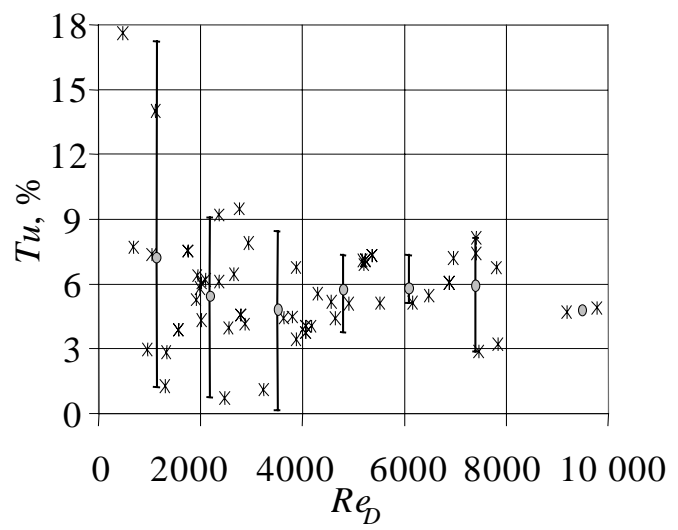

2 pav. Tu intensyvumo ir jo sklaidos, matuotų LDA, priklausomybè nuo $R e_{D}$

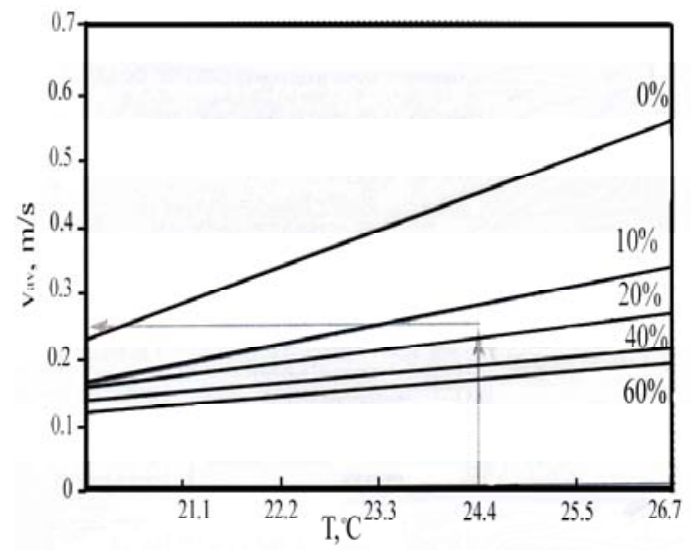

3 pav. Maksimalios $v$ vertès priklausomybė nuo $T u$ ir $T$

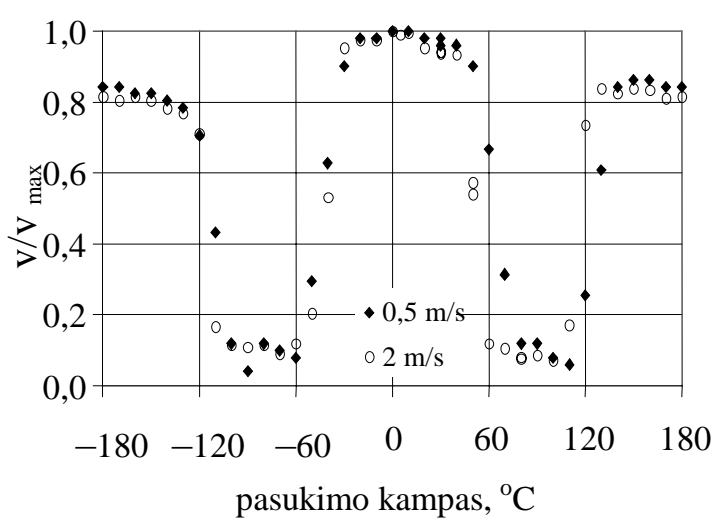

4 pav. Lokalinio $v$, matuoto vieliniu TA, verčių santykio ir maksimalių $v$ verčiu priklausomybè nuo pasukimo kampo

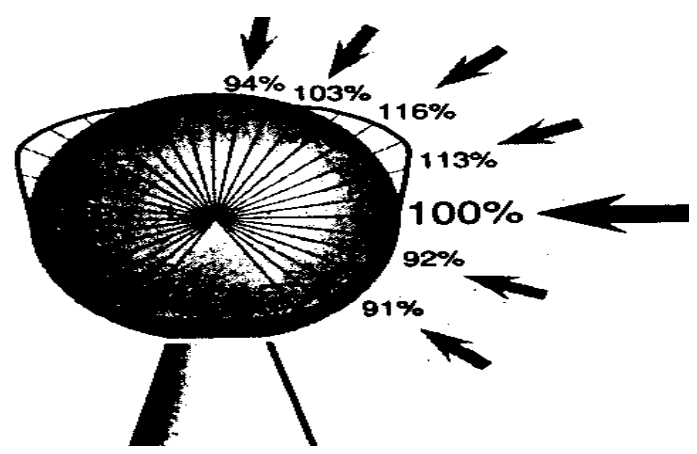

5 pav. TA su sferiniu jutikliu vertės priklausomybė nuo sferos pasukimo kampo

\section{Išvados}

1. Aplinkos oro sąlygoms tirti naudojamų prietaisų tikslumui turintys įtakos veiksniai turi būti ịvertinti kompleksiškai, norint kontroliuoti numatytus parametrus tinkamomis gyvenimo ir darbo sąlygomis.

2. Komfortiniu sąlygu parametrai yra labai nepastovūs ir veikiami daugelio veiksniu, kuriuos ivertinti ir išlaikyti nèra paprasta.

\section{Literatūra}

Jorgensen, F. E. 2005. How to measure turbulence with hotwire anemometers.

HN 42:2004 Higienos norma. 200407 06. „Gyvenamuju ir viešojo naudojimo pastatų mikroklimatas“. Valstybès žinios, Nr. 105-3911.

Ho, C. 1994 17-18 May. Air movement simulation of natural ventilation in a new administration building with two open atria. Flovent User Group Meeting. 
Measuring instruments for velocity. 2008. TESTO. 0981 7074/msp/Si/A/01. p. 1-36.

Nielsen, P. V.; Restive, A.; Whitelaw, J. H. 1978. The velocity character-ristics of ventilated rooms. J. of Fluids Eng. 100(9): 291-298.

Pedišius, A. 2009. Skysčiu ir duju tūrio/debito ir greičio vienetu valstybès etalonu (4 vnt.) naudojimas, tyrimas ir išlaikymas 2008 metais. Ataskaita. 48 p.

Pedišius, A.; Janušas, V.; Bertašienė, A. 2008. Low air velocity measure-ment characteristics' variation due to flow regime, International Journal of Fluid and Thermal Engineering. ISSN 2070-3759.

Rem, M. 1998. The Measurement and Simulation of Indoor Air Flow. ISBN $906814085 \mathrm{X}$.

Straube, J. 2001. Air flow control in building enclosures, in 8th Building Science and Technology Conference. Toronto, 282-302.

\section{AIR CONDITIONS EVALUATION QUALITY AND ACCURACY IN RESIDENTIAL AND WORKING PLACES USING MEASURING THERMAL ANEMOMETERS}

\section{A. Bertašienè}

Summary

Airflow movement and thermal parameters of indoor microclimate are discussed in this paper reviewing satisfaction of hygiene standards required for residential and working places in real conditions. Accuracy and influencing factors for measurement devices (thermal anemometers) for the range of low velocities are revealed. 